Information for Authors
The purpose of the Canadian Journal of Philosophy is the publication in Canada of philosophical work of high quality, in English or French, and in any field of philosophy. All submissions are given blind editorial review; those of departmental colleagues are externally refereed.

Manuscripts should be sent in triplicate to: Executive Secretary, Canadian Journal of Philosophy, Department of Philosophy, University of Lethbridge, Lethbridge, Alberta, Canada T1K 3M4. It is preferred that manuscripts be typed double-spaced, including quotes and footnotes. In general, the Canadian Journal of Philosophy follows The University of Chicago Manual of Style. Footnotes should be numbered consecutively and assembled on separate pages at the end of the manuscript. Manuscripts will not be returned unless return postage is prepaid by cheque, money-order, reply coupons, or Canadian stamps.

Authors will receive, without charge, 25 copies of their articles. Additional offprints may be ordered when the proofs are returned to the publisher.

The articles in C.J.P. are indexed in The Philosophers' Index, Bowling Green, Ohio, U.S.A., in the Reportoire bibliographique de la philosophie, Louvain, Belgium, and in the Canadian Periodical Index.

All enquiries of an editorial nature should be directed to the Executive Secretary at the above address.

The Canadian Journal of Philosophy a pour objet la publication canadienne, en langues anglaise ou française, d'études philosophiques de haut niveau, quel que soit le domaine philosophique auxquelles elles appartiennent. Les communications sont évaluées dans l'anonymat de leurs auteurs; celles que soumettent les collègues départementaux sont référées à un comité de lecture extérieur.

Les manuscrits, en triple exemplaire, doivent être adressés à La Secrétaire de Rédaction. Canadian Journal of Philosophy, University of Lethbridge, Lethbridge, Alberta, Canada T1K 3M4. Soumettre de préférence des manuscrits (citations et notes comprises) dactylographiés à double interligne, en prenant pour guide, dans la mesure du possible, The University of Chicago Manual of Style. Les notes doivent suivre la numérotation continue et figurer sur des feuilles indépendantes en annexe au manuscrit. Les textes non insérés ne sont rendus qu'en cas de prépaiement des frais de poste par chèque, mandat, coupons-réponse ou timbres canadiens.

Les auteurs recoivent gratuitement 25 tirés-à part de leur article. Ils sont priés, s'ils désirent en obtenir un plus grand nombre à titre onéreux, en informer l'imprimeur lors du renvoi des épreuves.

Les articles du C.J.P. sont catalogués dans The Philosopher's Index, Bowling Green, Ohio, E.-U., dans le Répertoire bibliographique de la philosophie, Louvain, Belgique, et dans l'Index de Périodiques Canadiens. 
Subscription Information
The Canadian Journal of Philosophy is published by the University of Calgary Press. Its sponsor is the Canadian Association for Publishing in Philosophy.

The Canadian Journal of Philosophy is published quarterly, in March, June, September and December. In addition to these regular issues, the C.J.P. publishes annually a supplementary volume of original papers on a selected theme of contemporary philosophical interest. This supplementary volume is free to individual and student subscribers to the journal in that year. Supplementary volumes may also be purchased separately.

Correspondence regarding subscriptions, renewals, single issues and supplementary volume orders should be addressed to Canadian Journal of Philosophy c/o The University of Calgary Press, University of Calgary, Calgary, Alberta, Canada T2N 1 N4.

A subscription for the 1988 volume of four issues is:

$\begin{array}{lrr} & \text { Canada } & \text { Outside Canada } \\ \text { Institutions } & \text { Cdn. } \$ 35.00 & \text { US } \$ 36.00 \\ \text { Individuals } & 20.00 & 20.00 \\ \text { Students } & 13.00 & 13.00 \\ \text { Single issues } & 9.00 & 9.00\end{array}$

A joint subscription to Canadian Journal of Philosophy and the Australasian Journal of Philosophy is available to individuals at $\$ 34$ and to students at $\$ 20$. Residents of Canada, Australia and New Zealand may remit in their respective currencies; for all others, prices are in US dollars.
The University of Calgary Press, The University of Calgary, CALGARY, Alberta, Canada T2N 1N4
1988 Subscription $\square \quad$ Individual $\square$ 1988 Joint Subscription $\square \quad$ Student Back Issue $\square$ No.

Please send me information on C.J.P. Supplementary Volumes

Name

Address

City

Country Postal Code

Visa $\square \quad$ Mastercard $\square \quad$ No.

Expiry Date Signature

Cheques should be made payable to The University of Calgary Press. 
Abonnements The Canadian Journal of Philosophy est publié par The University of Calgary Press sous l'égide de l'Asssociation Canadienne de Publications en Philosophie.

The Canadian Journal of Philosophy est une publication trimestrielle paraissant en mars, juin, septembre et octobre. Outre ses quatre fascicules réguliers, il publie, annuellement, un supplément thématique d'articles inédits consacrés à des sujets d'actualité philosophique. Le supplément est offert gratuitement à tout abonné - particulier ou étudiant - de l'année courante. Les suppléments sont également disponibles à titre onéreux.

Toute correspondance concernant l'administration (abonnements, renouvellements, commandes de numéros et de suppléments) doit être adressée à The Canadian Journal of Philosophy, clo The University of Calgary Press, The University of Calgary, Calgary, Alberta, Canada T2N 1N4. Tarifs d'abonnement au volume 1988 (4 fascicules):

$\begin{array}{lrr} & \text { Canada } & \text { Hors-Canada } \\ \text { Institutions } & \text { Cdn. } \$ 35.00 & \text { US } \$ 36.00 \\ \text { Individus } & 20.00 & 20.00 \\ \text { Etudiants } & 13.00 & 13.00 \\ \text { Numéro simple } & 9.00 & 9.00\end{array}$

Tout individu ou étudiant peut souscrire, à raison de $\$ 34$ et $\$ 20$ respectivement, un double abonnement au Canadian Journal of Philosophy et à l'Australasian Joumal of Philosophy. Règlement acceptable en monnaie nationale pour les résidents du Canada, de l'Australie et de la Nouvelle-Zélande; pour tous les autres, règlement en dollars US.

The University of Calgary Press,

Abonnement $1988 \square \quad$ Individu $\square$

The University of Calgary,

CALGARY, Alberta, Canada

Canadian

Veuillez me faire parvenir tous les renseignements concernant les suppléments du C.J.P.

Nom

Adresse

Ville

Pays

Code Postal

Visa $\square \quad$ Mastercard $\square \quad$ No.

Date d'expiration Signature

Libeller tout chèque à l'ordre de The University of Calgary Press. 


\section{Other \\ Business Information}

\section{Automatic Permission to Reproduce.}

All business correspondence, except that regarding subscriptions, renewals and single orders, should be addressed to The Managing Editor, C.J.P., Department of Philosophy, University of Calgary, Calgary, Alberta, Canada T2N 1N4. This includes enquiries concerning advertising and promotion, exchanges, and reprinting. The copyright for all materials appearing in the regular issues and in the supplements of this journal is held by the Canadian Journal of Philosophy, and consent for any reproduction or reprinting must be obtained from the Managing Editor, with the following exception.

Permission to reproduce parts of individual numbers of Canadian Journal of Philosophy by photocopy, xerox, offset, etc., for scholarly purposes (but not for republishing by printing nor for sale to the public) is automatically granted without prior permission being secured at the following rates:

0-5 copies, no charge; 6-20 copies, 4 cents for each copy of each page of C.J.P.; additional copies, 2 cents for each copy of each page of C.J.P.

Remuneration is to be paid to the Canadian Journal of Philosophy and addressed to the Managing Editor, stating title and author of the article and number of copies. Proceeds above $\$ 10.00$ from any one article will be shared equally with the author. This announcement applies retroactively to volume I, number 1 .

Toute correspondance administrative, à l'exception de celle qui concerne les abonnements, renouvellements et commandes de numéros et de suppléments, doit être adressée à La Directrice de la Publication, C.J.P., Department of Philosophy, The University Calgary, Calgary, Alberta, Canada T2N 1N4. Ecrire à l'adresse ci-dessus pour tous renseignements relatifs à la publicité et à la promotion, ainsi qu'aux échanges et aux réimpressions. Le copyright des articles afférents aux fascicules et suppléments est propriété du Canadian Journal of Philosophy. Leur reproduction ou réimpression en tout ou partie ne peut être faite sans l'agrément préalable de la Directrice de la Publication, sauf dans le cas suivant.

\section{Reproduction affranchie d'agrément préalable}

Est affranchie d'agrément préalable la reproduction partielle des numéros du Canadian Journal of Philosophy par procédé technique de photocopie, xerox, offset, etc., lorsqu'elle vise exclusivement à des fins ou à des recherches académiques. Est interdite toute réimpression ayant pour objet la vente au public. Conditions tarifaires de reproduction:

$0-5$ copies, accordé à titre gracieux; $6-20$ copies, 4 cents par page du C.J.P.; copies supplémentaires, 2 cents par page du C.J.P.

Effectuer tout règlement à l'ordre du Canadian Journal of Philosophy et l'adresser à La Directrice de la Publication, C.J.P. Avoir soin d'indiquer le nom de l'auteur et le titre de l'article à reproduire d'une part, et le nombre de copies requises, de l'autre. Les apports provenant d'un article sont partagés à égalité avec son auteur pour la part numéraire dépassant $\$ 10.00$ (règlement rétroactif au volume I, No. 1). 


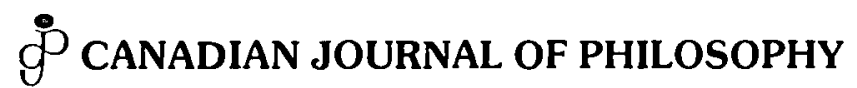

\author{
SUPPLEMENTARY VOLUME 13, 1987
}

\section{SCIENCE, MORALITY AND FEMINIST THEORY}

Editors: Marsha Hanen and Kai Nielsen

Introduction: Toward Integration

Marsha Hanen

Two Aspects: Science and Morality

Sex Inequality and Bias in Sex

Differences Research

The Need for More Than Justice

Alison M. Jaggar

Annette C. Baier

Critiques: Science, Ethics and Method

The Philosophy of Ambivalence: Sandra Harding on The Science Question in Feminism

Ascetic Intellectual Opportunities: Reply to Alison Wylie

Alison Wylie

Beyond Caring: The De-Moralization of Gender

Non-Contractual Society

Rawls and Ownership: The Forgotten

Category of Reproductive Labour

Ethics, Ideology, and Feminine Virtue

Women and Moral Madness

Moral Sanity or Who Killed Boy Staunton

Rescuing Womanly Virtues: Some Dangers of

Moral Reclamation

Sandra Harding

Marilyn Friedman

Virginia Held

Sibyl Schwarzenbach

John Exdell

Kathryn Morgan

Steven Burns

Barbara Houston

Some Applications

Feminist Ethics and In Vitro Fertilization

Surrogate Motherhood

Susan Sherwin

Christine Overall

Selves and Integration

Only Connect: The Place of Self-Knowledge in Ethics

Sheila Mullett

A Feminist Aspect Therapy of the Self

Ann Ferguson

Second Persons

Lorraine Code

Afterword: Feminist Theory - Some Twistings and Turnings

Kai Nielsen

This Supplementary Volume is free to individual and student subscribers to CJP Volume 17, 1987.

\section{PRICE:}

CDN $\$ 14.00$ in Canada US $\$ 12.00$ outside Canada. Please add $\$ 1.50$ for postage and handling, and $50 \notin$ for every further copy.

ORDER FROM:

The University of Calgary Press, LT1013, The University of Calgary, 2500 University Drive N.W., CALGARY, Alberta T2N 1N4 CANADA. 


\section{Noûs}

Prof. Hector-Neri Castañeda, editor

Prof. Earl Conee, associate editor

VOLUME 22, NO. 3

SEPTEMBER 1988

Articles: Patrick Crim/Logic $\mathcal{E}^{2}$ Limits of Knowledge $\mathcal{E}^{2}$ Truth; Radu Bogdan/Mental Allitudes E' Common Sense Psychology; Jonathan BennetUQuotation; William Hasker/ Hard Facis $\mathcal{E}^{2}$ Theological Fatalism; Daniel Farrell/Punishment Without the State; Charles Daniels/Perception, Thought \&ٔ Reality.

Critical Reviews: Graeme Forbes by Peter Simons; Irving Singer by Robert Solomon; John Rajchman \& Cornell West by Henry Veatch; Scott Meikle by Milton Fisk; Philip Kitcher by Claudia Murphy; Richard Fumerton by Georges Dicker.

VOLUME 22 , NO. 4

DECEMBER 1988

Articles: Glenn Hartz \& J.A. Cover/Space \& Time in the Leibnizian Metaphysic; John Dupre \& Nancy Cartwright/Probability E' Causality; Ingmar Persson/Rationality, $\mathcal{E}^{2}$ the Maximization of Satisfaction; George Panichas/Hobbes, Prudence, and Basic Rights; A.W. Moore/What Does Godel's 2nd Incompleteness Theorem Show?

Critical Study: John Searle by William Rapaport.

Critical Reviews: Daniel Dennett by Peter van Inwagen; G.P. Baker \& P.M.S. Hacker by Paolo Leonardi; Raimo Tuomela by Myles Brand; Kit Fine by Marco Santambrogio; Norman Kretzmann by Mauricio Beuchot; C. Behan McCullagh by Wright Neely; Gianni Rigamonti by Francesco Orilia.

Subscribe to:

Noûs \% Secretary

Submissions to:

Dept, of Philosophy

1988 Subscriptions:

Indiana University

Institutions: $\$ 45.00$

Noûs \% Editor

Sycamore 126

Individuals: $\$ 22.00$

Bloomington, IN 47405 Single Issues: $\$ 12.00$

Whosemghts?

Masce responstbithes?

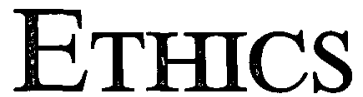

AND

AGING

The Right to Live, The Right to Die edited by

JAMES E. THORNTON \& EARL R. WINKLER
An important and timely look at issues of ethics in aging, this book addresses questions of great concern to society and the elderly. It incorporates viewpoints from gerontology, philosophy, law, theology, sociology, medicine, and economics.

cloth $\mathbf{\$ 3 4 . 9 5}$ paper $\$ \mathbf{1 6 . 9 5}$

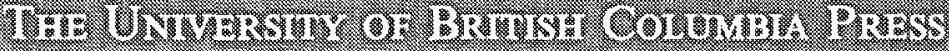

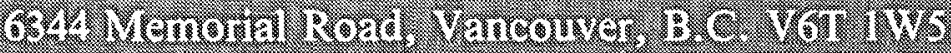




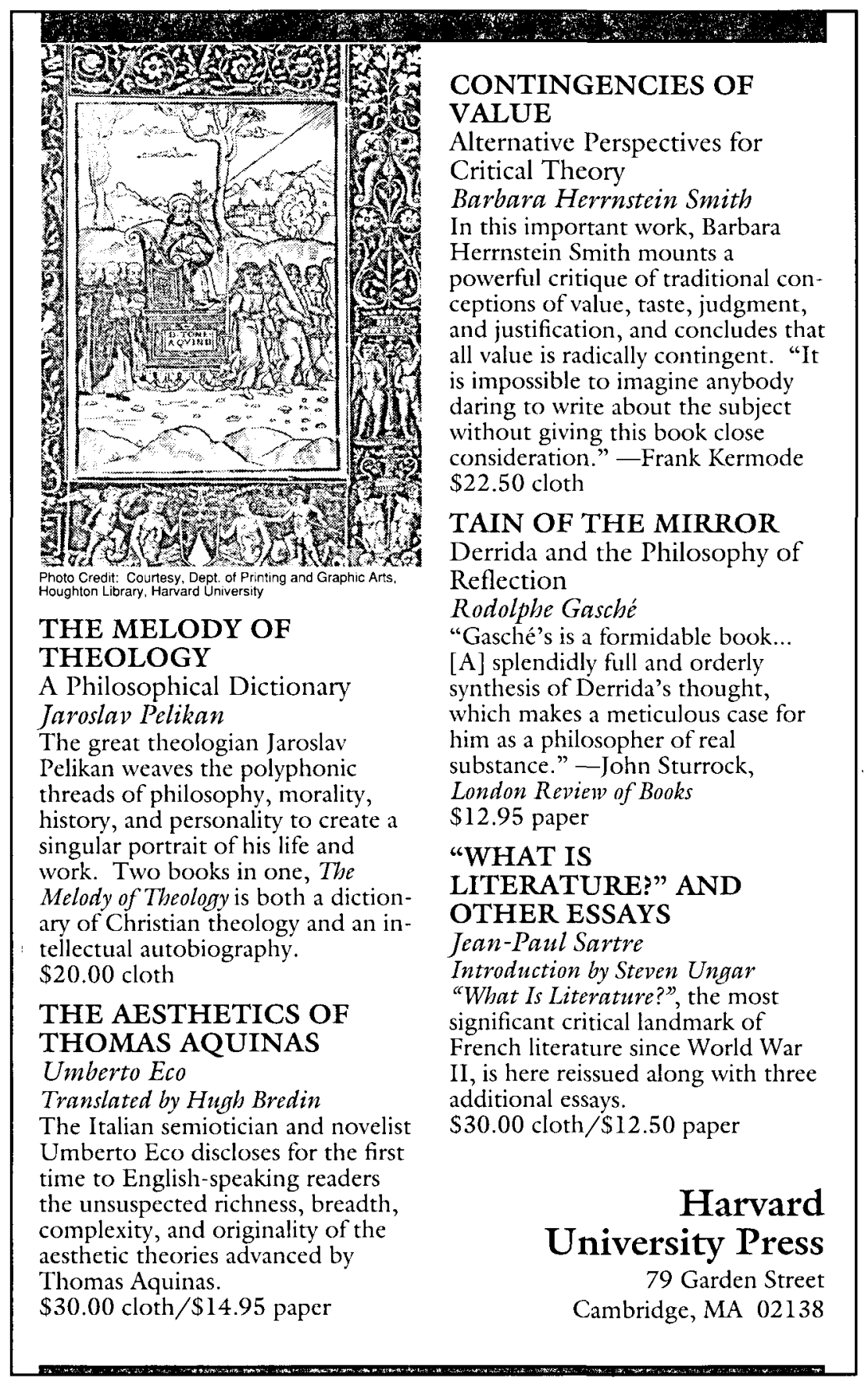




\title{
Philosophical Studies
}

\section{An International Journal for Philosophy in the Analytic Tradition}

Editor-in-Chief

John Pollock, Dept. of Philosophy, University of Arizona, Tucson, USA

Philosophical Studies is devoted to the publication of analytical contributions, particularly (but not exclusively) in epistemology, philosophical logic, the philosophy of language, and ethics. The principal aim is to publish articles that are models of clarity and precision in dealing with some significant philosophical issues. Articles in the journal are intelligible to philosophers whose expertise lies outside the subject matter of the article.

\section{Subscription Information}

ISSN 0031-8116

1988, Volume 53-54 (6 issues)

Institutional rate: Dfl. 422.00/US $\$ 200.00$ incl. postage/handling

Private rate: Dfl. $164.00 /$ US $\$ 69.00 \mathrm{incl}$. postage/handling

Private subscriptions should be sent direct to the publishers

D. Reidel Publishing Company

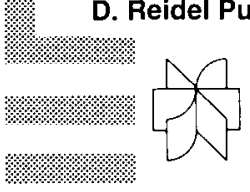

Kluwer Academic Publishers

P.O. Box 989,3300 AZ Dordrecht, The Netherlands 101 Philip Drive, Norwell, MA 02061 , U.S.A.

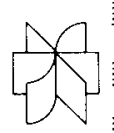

\%)

\section{PHILOSOPHY \\ OF THE SOCIAL SCIENCES \\ PHILOSOPHIE DES SCIENCES SOCIALES}

\author{
Volume 17, Number 4, December 1987
}

\section{Articles}

Hans Albert and the Unfinished Enlightenment by C. Fred Alford

On Situating Piaget's Subject: A Triangulation Based on Kant, Structuralism, and Biology by Ian Jackson

Emotion and Error by John D. Greenwood

Article-Review's

Philosophy, Economics and Capital Theory by Robert J. Wolfson

Sexism in Science by Joseph Agassi and Judith Buber Agassi

The Middle Years of Psychoanalysis: The Two Great Ladies and Others by J. O. Wisdom

Science and Scepticism by Brian Baigrie

A Review of Roger Waterhouse's A Heidegger Critique, by Mildred Bakan The Poverty of Current Forensic Psychiatry by Nathaniel Laor

Fiction Science by Edward Davenport

Orders to:

Wilfrid Laurier University Press

Waterloo, Ontario, Canada N2L 3C5
Subscription Rate: $\$ 30.00$ per year for four issues Single issues: $\$ 8.00$

An International Journal

Edited by J. O. Wisdom, I. C. Jarvie, John O'Neill, and J. N. Hattiangadi at York University, Toronto 


\section{Journal of Philosophical Logic}

\section{Editor-in-Chief}

Richmond H. Thomason, Dept. of Philosophy, University of Pittsburgh, USA

The Journal of Philosophical Logic is the only journal specializing in philosophical logic and utilizes formal methods of dealing with topics in logical theory.

\section{Subscription Information}

ISSN 0022-3611

1988, Volume 17 (4 issues)

Institutional rate: Dfl. 228.00/US\$108.00 incl. postage/handling

Private rate: Dfl. $82.00 / \mathrm{US} \$ 31.50 \mathrm{incl}$. postage/handling

Special rate for ASL members: Dfl. $62.00 / \cup S \$ 21.50$ incl. postage/handling

Private subscriptions should be sent direct to the publishers

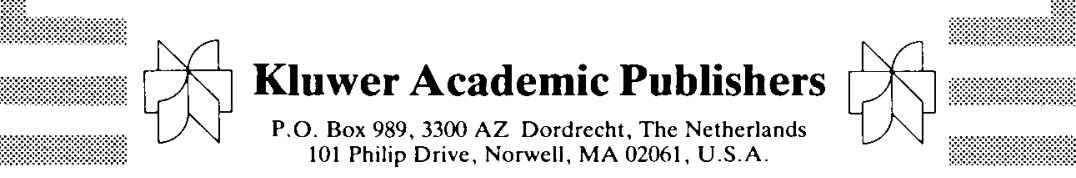

\section{\$ Thilosophy}

Teaching Philosophy is a quarterly journal which serves as a forum for the exchange of ideas and information about the teaching and learning of philosophy. Articles, discussions, reports and reviews are published on topics such as:

- theoretical issues in the teaching of philosophy

- innovative methods and classroom stratagems

- experimental and interdisciplinary courses

- faculty development and student counseling

1988 Subscriptions: $\$ 18.50$ individuals; $\$ 42$ institutions. Add $\$ 4$ for all subscriptions outside the U.S. Order from the PHILOSOPHY DOCUMENTATION CENTER, Bowling Green State University, Bowling Green, OH 43403-0189 USA.

Edited by: Arnold Wilson, University of Cincinnati, Cincinnati, $\mathrm{OH}$ 45221-0206. 


\section{ARCHIVES \\ $\mathrm{DE}$ PHILOSOPHIE}

Revue trimestrielle publiée avec le concours du Centre National de la Recherche Scientifique et de la Fondation de Montcheuil

Tome 51 - Cahier 1 - Janvier-Mars 1988

LES PREMIERS ÉCRITS DE SPINOZA

Pierre-François Moreau

Edwin CuRLey

Charles Ramond

Joël Ganault

Gabriel Albiac

Giuseppa Saccaro Battisti

Bernard Roussex

Marie-Hélène BeLIN

Elkhanan YAKIRA
Un colloque sur le * jeune Spinoza *

Le corps et l'esprit : du Court Traité à l'Éthique

Les mille et une passions du Court Traité Immanence et transcendance dans le Court Traité

* Recuperar lo passado*. L'axe épicurisme/ machiavélisme dans l'histoire apologétique d'Abraham Pereyra

Abraham Cohen Herrera et le jeune Spinoza - entre kabbale et scolastique : à propos de la création «ex nihilo»

La première Ethique. Méthode et perspectives

Les principes de la philosophie de Descartes: remarques sur la duplicité d'une écriture

Boyle et Spinoza

Comptes rendus

Équipe DESCARTES C.N.R.S.

Bulletin Cartésien XVI

Tome 51 - Cahier 2 - Avril-Juin 1988

Miguel EsPinoza

Jocelyne LEBRUN

Sylvain ZAC
Les mathématiques et la nature

Pour une phénoménologie de l'imagination poétique

L'idée de chose en soi dans la philosophie de Salomon Maimon

Bulletin Hobbes I

Comptes rendus

RÉDACTION : Les Fontaines - F 60500 CHANTILLY CEDEX

ABONNEMENTS : Beauchesne, 72, rue des Saints-Pères, 75007 PARIS
Prix de l'abonnement annuel (4 cahiers) :
France............... 260 F (ttc)
Etranger ................ $330 \mathrm{FF}$
Le cahier (France)......... $90 \mathrm{~F}$
(Etranger) ........ $90 \mathrm{FF}$
C.C.P. trois volets à l'ordre de Beauchesne ou chèque bancaire 


\title{
crítica
}

Vol. XIX / No. 55 / México, Abril 1987

Artículos

JUAN A NUÑO, Esto no tiene nombre

LEILA Z. PUGA y NEWTON C.A. DA COSTA, Sobre a lógica deôntica não-clássica

LORENZO PENAA, Frege's Theory of Relations and the Search for a Workable Alternative

Discusiones

LOURDES VALDIVIA, Nombres y predicados: Algunas consideraciones

OLBETH HANSBERG, Sobre la filosofía de Donald Davidson

Notas bibliográficas

MERRIL B. HINTIKKA Y JAAKO HINTIKKA, Investigating Wittgenstein [Alejandro Tomasini]

NOTICIA

Publicaciones recientes

CRÍTICA, Revista Hispanoamericana de Filosofia is published in April, August and December. All correspondence should be addressed to CRÍTICA, Apartado 70-447, Coyoacán, 04510-México, D.F. México.

\section{THE CLASSICAL WORLD}

Published six times yearly (from September to July). Each volume contains approximately 400 pages. Paid international circulation of more than 3,000.

Since $1907 \mathrm{CW}$ has provided a combination of services and fea. tures which make the journal an indispensable tool for teaching and research in the Classics.

ARTICLES ...

of scholarly and general interest to students of Graeco-Roman culture and its aftermath.

\section{SURVEYS...}

complete and annotated bibliographical surveys of scholarship on authors, genres, special areas.

REVIEWS...

$C W$ specializes in the brief and expert review of new books in all areas of Classical Antiquity and related subjects.

\section{BOOKS RECEIVED . . .}

extensive and immediate listing of all books received from pub. lishers around the world with complete bibliographical information.

For a free sample copy of $C W$ and subscription blank write to

\author{
The Classical World \\ Department of Classics \\ Duquesne University \\ Pittsburgh, PA 15282
}




\section{THE CLASSICAL WORLD}

Since 1907 THE CLASSICAL WORLD has provided a combination of services and features which make the journal an indispensable instrument for teaching and research in the Classics. It is published six times yearly - from September to July.

\section{Articles}

Volume 82 will contain among others the following articles of scholarly and general interest to students of Graeco-Roman Culture:

"Horace's Soracte Ode: Location, Dislocation, and the Reader", "Servile Behavior in Sallust's Bellum Catilinae", The Age of Marriageability at the Argead Court: 360-317 B.C.", "Toward a Semantics of Ancient Conflict: ERIS in the Iliad", "Mime: The Missing Link in Roman Literary History", "The Central Similes of Horace's Cleopatra Ode", "Meter and Emotion in Ovid's Exilic Poetry", "Cicero and the "Gang of Five'", "Actors and Act-Divisions in the Greek Original of Plautus' Menaechmi", and "Homer and the Life-producing Earth".

$C W$ will offer as well a full survey of audiovisual materials and a supplementary survey of currently available annotated Greek and Latin texts.

\section{Reviews}

THE CLASSICAL WORLD specializes in brief and expert reviews of new books in all areas of classical antiquity. Volume 82 will feature approximately 120 such reviews.

\section{Books Received}

The journal of fers extensive and immediate listings of all books received from publishers around the world with complete bibliographical information.

For subscription information, write:

THE CLASSICAL WORLD

Department of Classics

Duquesne University

Pittsburgh, PA 15282 


\section{critica}

Vol. XIX / No. 56 / México, Agosto 1987

Artículos

MORRIS LAZEROWITZ, Wittgenstein: The Nature of Philosophy

BARRY BARNES, Concept Application as Socjal Activity

CARLOS SANTIAGO NINO, The Concept of Moral Person

JULIÁN GARRIDO GARRIDO, Formulaciones del segundo principio de la termodinámica

Notas bibliográficas

JOSE LUIS D LAZ, Análisis estructural de la conducta [M. Valdés]

Libros recibidos

CRITICA, Revista Hispanoamericana de Filosofía is published in April, August and December. All correspondence should be addressed to CRÍTICA, Apartado 70-447, Coyoacán, 04510-México, D.F. México.

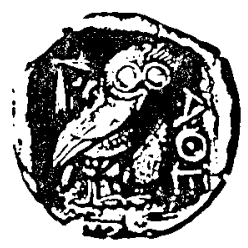

\section{SPINDEL CONFERENCE}

\section{8}

\section{ARISTOTLE'S ETHICS}

Julia Annas - Self-Love in Aristotle (Richard Kraut-Comments). John Cooper - Some Remarks on Aristotle's Moral Psychology (Gisela Striker-Comments). Terence Irwin - Sentiments of the Understanding and Perceptions of the Heart (John McDowell-Comments). Timothy Roche - The Perfect End (Steven White - Comments). Susan Sauvé - Why Forced Actions are Painful and How Mixed Actions are Mixed (Jennifer Whiting - Comments). Nicholas White - Good as Goal: Naturalism and Anti-Naturalism in Aristotle's Ethics (Daniel Devereux - Comments). Charles Young - Aristotle on Justice (David Key' Comments).

SUPPLEMENT TO THE SOUTHERN JOURNAL OF PHIIOSOPHY. VOI. XXVII. 1988. Individual copics $\$ 10.00$. Free with each $\$ 12.00$ annual subscription to THE SOUTHERN JOURNAL OF PHILOSOPHY. Mcmphis State University, Memphis. TN 38152, U.S.A. 


\title{
the rewiew of
}

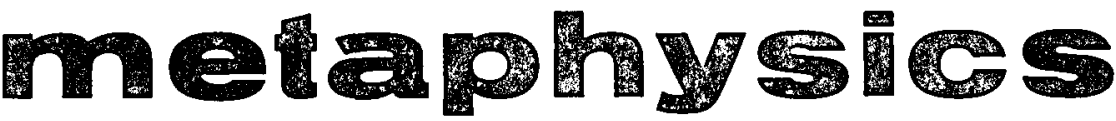

a philosophical quarterly

SEPTEMBER 1988

VOL. XLII, No. $1 \quad$ ISSUE No. $165 \mid$ | \$9.00

\section{articles \\ KENNETH L. SCHMITZ \\ ROBERT SOKOLOWSKI \\ DAVID INGRAM \\ JEROME NEU \\ REYNOLD SIEMENS \\ ALISTAIR MORRISON and \\ Staff}

philosophical abstracts

Individual Subscriptions \$23.00

\section{Neither with nor without Foundations \\ Referring}

The Postmodern Kantianism of Arendt and Lyotard

Divided Minds: Sartre's "Bad Faith" Critique of Freud

Hegel and the Law of Identity

Summaries and Comments

\section{REVUE INTERNATIONALE DE PHILOSOPHIE}

\author{
Editor: Michel MEYER
}

143, av. A. Buyl, 1050 Brussels, Belgium

Each number is devoted to a particular movement, a particular philosopher, or a particular problem.

We publish 3 issues annually. Articles are written in English, French, German, or Italian.

Coming numbers

Locke

Kant and Practical Reason

Artificial Intelligence

Heidegger

Wittgenstein

Our last issue was devoted to Schopenhaver

(articles by D. W. Hamlyn, D. E. Cartwright, W. Schirmacher and K. Boullart) 
A Journal of Feminist Philosophy

Hypatia is dedicated to the publication of scholarly research in feminist philosophy and provides a forum not available in other women's studies or mainstream journals.

"The scholarly papers in Hypatia will undoubtedly be core references in debates on feminism, and will have application in many social science disciplines as well." Choice

Annual subscriptions ( 3 issues) are available to individuals at $\$ 20$ and to institutions at $\$ 40$. Further information, including bulk order discounts, is available from:

Journals Division

Indiana University Press

10th \& Morton Streets

Bloomington, Indiana $\mathbf{4 7 4 0 5}$

\section{$\oint$ CANADIAN JOURNAL OF PHILOSOPHY}

RECENT SUPPLEMENTARY VOLUMES

(1981 $\quad$ 1987)

\begin{tabular}{|c|c|c|c|}
\hline & (1981 & $\begin{array}{l}\text { In } \\
\text { Canada }\end{array}$ & $\begin{array}{l}\text { Outside } \\
\text { Canada }\end{array}$ \\
\hline VOL.UME VII & $\begin{array}{l}\text { MARX \& MORALITY } 1981 \quad 379 \text { pp } \\
\text { edited by Kai Nielsen and Steven Patten }\end{array}$ & $\$ 15.00$ & US\$15.00 \\
\hline VOLUME VIII & $\begin{array}{l}\text { NEW ESSAYS IN ETHICS AND PUBI.IC POLICY } \\
\text { edited by Kai Nielsen and Steven Patten } 1982 \quad 233 \text { pp }\end{array}$ & 515.00 & USS15.00 \\
\hline VOLUME IX & $\begin{array}{l}\text { NEW ESSA YS ON PLATO } 1983 \quad 185 \mathrm{pp} \\
\text { edited by Francis J. Pelletier and John King-Farlow }\end{array}$ & $\$ 15.00$ & US 515.00 \\
\hline VOLUME X & $\begin{array}{l}\text { NEW ESSAYS ON ARISTOTLE } 1984 \quad 191 \text { pp } \\
\text { edited by Francis J. Pelletier and John King-Farlow }\end{array}$ & $\$ 15.00$ & US\$15.00 \\
\hline VOLUME 11 & $\begin{array}{l}\text { NEW ESSAYS IN PIILOSOPHY OF MIND, Series II } \\
\text { edited by David Copp and J.J. MacIntosh } 1985\end{array}$ & 514.00 & US 514.00 \\
\hline VOLUME 12 & $\begin{array}{l}\text { NUCLEAR WEAPONS, DETERRENCE AND DISARMAMENT } \\
\text { edited by David Copp } 1986\end{array}$ & $\$ 12.00$ & US $\$ 10.00$ \\
\hline VOLUME 13 & $\begin{array}{l}\text { SCIENCE, MORALITY AND FEMINIST THEORY } \\
\text { edited by Marsha Hanen and Kai Nielsen } 1987\end{array}$ & $\$ 14.00$ & US $\$ 12.00$ \\
\hline
\end{tabular}

Postage and Handling: Add $\$ 1.50$ for one copy and $50 \notin$ for each further copy.

ORDER FROM:

The University of Calgary PRESS, Library Tower 1013, 2500 University Drive NW.

CALGARY, Alberta T2N 1N4 Canada 


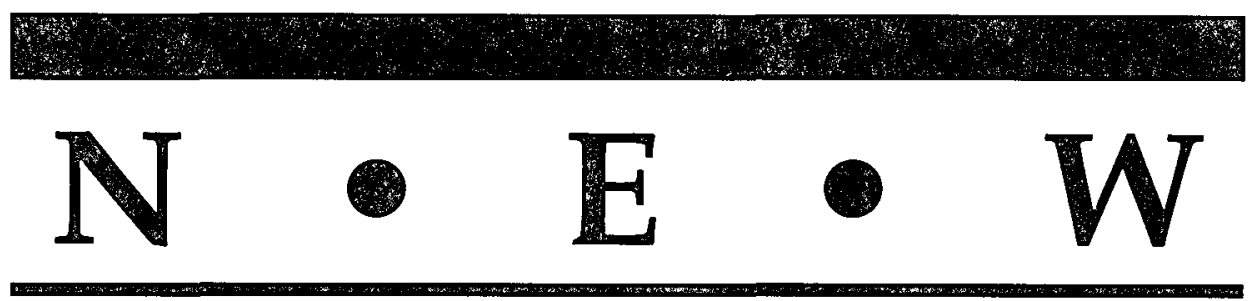

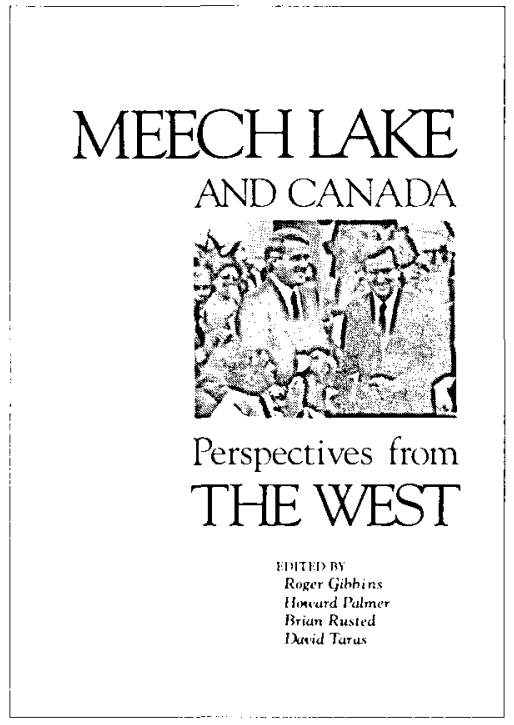

\section{4 pp. $\$ \mathbf{1 1 . 9 5}$}

(Limited clothbound library edition \$32.95)
FROM

Academic Printing \& Publishing

The Meech Lake Accord is one of the most significant constitutional agreements in Canadian history. It has great importance for every Canadian.

Meech Lake and Canada is the first book to meet the needs of students, teachers, scholars and all interested Canadians for a thorough analysis of the issues and events.

Academic Printing \& Publishing

P.O. Box 4834

Edmonton, Alberta, Canada

T6E 5G7

(403) $435-5898$ 


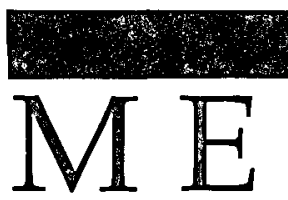

(2)

(4)

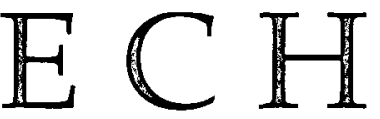

$\mathrm{L}$

A

$\mathrm{K}$

E

A N D C A N A D A

Edited by

Roger Gibbins

Howard Palmer

Brian Rusted

David Taras

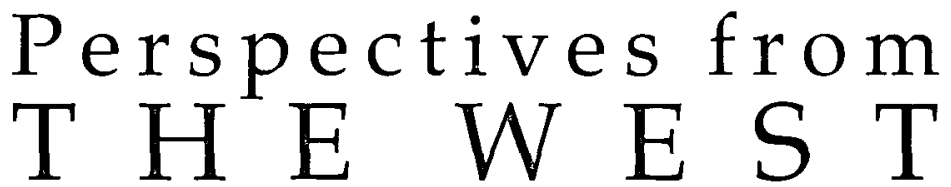

\section{T a}

Preface

I Introduction to

Constitutional Politics

II Meech Lake and the West Introduction

The Peace of the Graveyard David Bercuson, Department of History, The University of Calgary The Enigma of Meech Lake for Senate Reform

David Elton, Department of Political Science, The University of Lethbridge

Senate Reform:

Forward Step or Dead End?

Peter McCormick, Department of

Political Science, The University of Lethbridge

The Flaws of the Meech Lake Accord: An Alberta Perspective Howard Palnter, Department of History, The University of Calgary

The Courts:

Toward a Provincial Role in Judicial Appointments

Peter McCormick, Department of Political Science, The University of Lethbridge

Manitoba and the

Meech Lake Accord

Gerald Friesen, st. Paul's College,

University of Manituba

III Meech Lake and Quebec

Introduction

The Meaning and

Centrality of Recognition

Guy Laforest, Department of l'olitical

Science, The University of Calgary

Quebec and Meech Lake

Dale C. Thomson, Department of

Political Science, McGill University
Say Goodbye to the Dream of One Canada

Pierre Elliott Trudeau

\section{The Political Process}

Ottawa, The Provinces, and Meech Lake

Alan C. Cairns, Department of I'olitical Science, The University of British Columbia

A Sense of Unease: The Meech Lake Accord and ConstitutionMaking in Canada

Roger Gibbins, Department of Political Science, The University of Calgary

An Economic Perspective Malcolm C. Brown, Department of Economics, The University of Calgary

The 1987 Constitutional Accord and Federal-Provincial Relations Claude Rocan, Intergovernmental Affairs Branch, Government of Saskatchewan

Who Spoke For Canada?

Doreen Barrie, Department of Political Science, The University of Calgary

Meech Mumbles..

William $F$. Gold, columnist, The Calgary Herald

\section{Human Rights}

Introduction

Women's Rights

Kathleen Mahoney, Faculty of Law, The University of Calgary

The Meech Lake Accord and Multiculturalism Anthony Parel, Department of Political Science, The University of Calgary
Minutes of Proceedings and Evidence of the Special Joint Committee of the Senate and of the House of Commons on The 1987 Constitutional Accord Chief George Erasmis, National Chief of the Assembly of First Nations

The Francophone Minority

Karen Taylor-Browne, Department of Linguistic Science, The University of Reading

Constitutional Reform and Immigration

Orest Kruhlak, Department of Political Science, The University of British Columbia

VI Meech Lake and the Media

Introduction

Meech Lake and Television News

David Taras, Canadian Studies, The University of Calgary

Inside the News Story: Meech Lake As Viewed By An Ottawa Bureau Chief Elly Alboim, Ottawa Bureau Chief, $\mathrm{CBC}$

Fractured Mirror:

The Importance of Region and Personalities in

English Language Newspaper Coverage of Meech Lake

Lorry Felske, Canadian Studies, The University of Calgary

VII The Road Ahead

Appendix: The Constitution Amendment 1987

Biographies of Contributors

Academic Printing \& Publishing P.O. Box 4834, Edmonton, Alberta, Canada T6E 5C7 
Acknowledge- The Canadian Journal of Philosophy is published with the ments/ aid of a grant from the Social Sciences and Humanities Research Remerciements Council of Canada.

La publication du Canadian Journal of Philosophy est rendue possible grâce à un octroi du Conseil de Recherches $\mathrm{Hu}$ maines du Canada.

The Canadian Journal of Philosophy wishes to thank the University of Lethbridge for its generous support for the editorial administration of the journal.

The Canadian Journal of Philosophy tient à remercier l'Université de Lethbridge de l'aide généreuse qu'elle apporte à la gestion de sa rédaction.

The Canadian Journal of Philosophy is grateful for past support from its originating sponsor, the Canadian Association for Publishing in Philosophy. The Association is a non-profit organization, incorporated under the laws of Canada, with the object of promoting and publishing learned publications in philosophy. A regular member of the Association is a member of, and appointed by, any department of philosophy in a Canadian university, upon payment of a subscription by that department. The Association is a Registered Canadian Charitable Organization within the meaning of the Income Tax Act; donations to the Association are thus tax deductible.

The Canadian Journal of Philosophy désire exprimer sa gratitude à l'Association Canadienne des Publications en Philosophie qui l'a aidé par le passé. L'Association est un organisme à but non lucratif, incorporé aux termes de la loi canadienne, ayant pour objet la promotion et la publication d'études savantes en philosophie. Tout membre appartenant à, et désigné par, un département de philosophie d'une université canadienne est de facto, au reçu du règlement de l'abonnement départemental, membre à part entière de l'Association. L'Association est inscrite au Registre officiel des Organismes de Charité canadiens aux termes de la loi de l'impôt sur le revenu; les donations dont elle fait l'objet peuvent bénéficier ainsi du dégrèvement d'impôt. 